\title{
引用文献
}

1) V.M. Berezovskii, V.A. Kurdyukova, N.A. Preobrazhenskii, Zh. Obshch. Khim. 211163 (1951); ibid. 21 1269 72 (1951); C.A. 465006 (1952)

2) K. Sato, Y. Fujima, A. Yamada, Bull. Chem. Soc. Japan 41442 (1968)

3) E. Edler, Ber. 18629 (1885); S. Goldschmidt, Ber. 5339 (1920);

L. Marion, C.W. Oldfield, Canadian. J. Res. 25 B 1 (1947)

\section{Tetraphenylethylene-sodium adduct}

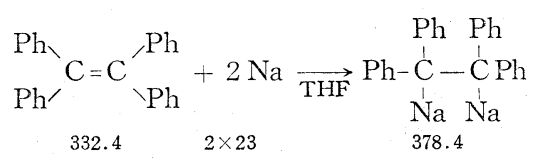

佐 藤 武 雄

（東京都立大学理学部）

I. 製 法

かきまぜ機，窒素導入管をそなえた $1 l$ の三つロフラスコに精製テトラヒドロフラン (THF)（注意 1 ) $200 \mathrm{~m} l$ を入 れ, $2.5 \mathrm{~g}(8 \mathrm{~m} \mathrm{~mol}) の$ tetraphenylethylene と $8 \mathrm{~g}(0.35 \mathrm{~g}$-atom) のナトリウムを加える。窒素を流しながら（注意 2 ), 別途に少量の tetraphenylethylene とナトリウムを少量の THF 中で反応させて作った付加体を種として加える。 まもなく全体が暗紫色の溶液となるから常温で一夜, あるいは還流冷却器をつけて数時間加熱する。窒素はこの間も流 しつづける。このナトリウム付加体溶液は各種八ロゲン化合物の縮合反応等にそのまま用いることができる（注意 3 ）。

\section{II. 注 意}

（1）ナトリウムで処理してから水素化アルミニウムリチウム上で蒸留したものを用いる。

(2) 窒素はコン跡の酸素を除くためFieser 溶液1を通すとよい。

（3） 付加体は湿気，酸素，あるいは二酸化炭素とすみやかに反応するので気密の保持に十分気をつける。

\section{III. 性質}

きわめて反応性に富む化合物であるので溶液のまま取り扱う。密センをしておけば保存に耐える。

\section{IV. 本法の利点}

ナトリウムとの反応が均一系条件下で行なえることになり ${ }^{2,3)}$ ，高希釈 Wurtz 反応を用いる各種シクロファンの合成 が容易となり，かつ収率が向上した4。この付加体溶液はきわめて反応活性で，芳香族フルオル化合物の反応も可能で 亦る4)。Wurtz 型反応によってナトリウムが消費されると tetraphenylethylene が再生され，これがさらに過剩のナト リウムと反応するので tetraphenylethylene の量法少量でよい点も本法の特徴である。

ナトリウムの代りにリチウムあるいは $\mathrm{Na}-\mathrm{K}^{5}$ を用いることもできる。溶媒にはジメトキシエタンを用いることも できる。

\section{引用文献}

1) L.F. Fieser, M. Fieser, "Reagents for Organic Synthesis" John Wiley and Sons, Inc., New York, N.Y. (1967) p. 393

2) E. Müller, G. Röscheisen, Chem. Ber. 90543 (1957)

3) E. Müller, G. Röscheisen, ibid. 911106 (1958)

4) 佐藤武雄, 日化 92277 (1971)

5) H.E. Zimmerman, G. Jones II, J. Am. Chem. Soc. 922753 (1970) 